\title{
Cytomegalovirus Infection among Patients with Chronic Hepatitis $C$ Virus and its relation to hepatitis $C$ virus load
}

\author{
Heba Mohamed ${ }^{1}$, Manal Mohamed El-Amin ${ }^{1}$, Hoda Abdeen ${ }^{1}$, Talaat Fathy ${ }^{2}$ \\ ${ }^{1}$ Clinical pathology Department, Faculty of Medicine, Zagazig University, Egypt \\ ${ }^{2}$ Tropical Medicine Department, Faculty of Medicine, Zagazig University, Egypt
}

Corresponding Author Talaat Fathy

Mobile:002010922147

81

E mail:

talaat_fathy1972@yah oo.com

Key words: Cytomegalovirus; $\mathrm{HCV}$; Viremia
Background and study aim: The clinical significance of Human Cytomegalovirus (HCMV) and its pathological effects have increased in the past 20 years and it became one of the common causes of disability and may be mortality in immuno-compromised hosts. This work aimed to assess the prevalence of HCMV infection in patients with chronic $\mathrm{HCV}$ and its correlation with HCV load in Clinical Pathology and Tropical Medicine departments, Faculty of Medicine, Zagazig University.

Patients and Methods: This study included 120 individuals between May 2015 to May 2016..They were assigned into two groups: Group I (Control group) Included 60 apparently healthy persons (34 male \& 26 female) with their age range from 21-60 years (mean 37.3 \pm 12.4 years). Group II (Patient group) Included 60 chronic HCV patients (40 male \& 20 female) with their age ranged from 20-62 years and mean age $37.5 \pm 11.9$ years (all were Child A according to Child-Pugh classification) and were subdivided into 4 subgroups according to viral load by quantitative PCR (where lower detection limit assay less than $15 \mathrm{IU} / \mathrm{mL}$ ) Resolved Group (viral load not detected), Mild viremia group (viral load: $<200,000$ $\mathrm{IU} / \mathrm{mL}$ ), Moderate viremia group (viral load: 200,000 - 2,000,000 IU/mL) and Severe viremia group (viral load: more than $2,000,000 \mathrm{IU} / \mathrm{mL}$ ) as measured by the National Genetics Institute assay.

Results: In this study; it was found that in HCV-positive group, serum ALT levels were higher in HCMV positive patients compared to HCMV negative patients. Also, there was a higher prevalence of CMV IgM among cases (28.3\%) compared to controls $(16.7 \%)$ while there was a higher percentage of CMV IgG among cases (91.7\%) compared to controls $(53.3 \%)$.

Conclusion: CMV infection is common in chronic HCV patients and there was no correlation between hepatitis $\mathrm{C}$ virus load and CMV IgG but there was positive correlation between hepatitis $\mathrm{C}$ virus load and CMV IgM. There was no correlation between hepatitis $\mathrm{C}$ virus load and CMV $\mathrm{IgG}$ in all patients' subgroups. Also there was no correlation between hepatitis C virus load and CMV IgM in mild and moderate cases but there was positive significant correlation between HCV viral load and CMV IgM in severe cases.

\section{INTRODUCTION}

The clinical significance of Human Cytomegalovirus (HCMV) had been reported increasingly in the past two decades. It was reported that over $70 \%$ of the populations are proved to be carriers of HCMV [1] and it is established as one of the causes of both co-morbidity and may be fatality in immunocompromised individuals [2].

Cytomegalovirus is a ubiquitous bherpes virus family which affects 60$80 \%$ of humans. Infection with CMV is more prevalent in the developing countries and usually controlled by the immune system without eradication. Instead, the virus remains in a latent state but reactivation may occur [3].

Reactivation may occur during times where the immune system is suppressed, by drugs, acute illness states, and other inflammatory diseases, or super infection by different pathogens $[4,5]$.

Viral interactions were reported to affect the pathogenesis of other viral infections [6]. Studies concluded that HCV and HBV co-infection exist and can suppress the replication of each other [7]. Co-infections with HBV and 
HIV in patients with HCV have been documented and was associated more progressive course of $\mathrm{HCV}$ and more aggressive histological changes enhancing the progression to cirrhosis and HCC [8]. Few studies investigated the co-incidence of CMV and chronic HCV [5].

It was reported that CMV infection had occurred with $\mathrm{HBV}$ and $\mathrm{HCV}$ patients and it was associated with a progressive form of chronic HCV. Bader El-Din et al. [9] reported that CMV HCV co-infection was higher among Egyptian patients than other populations.

Moreover, Lian et al. [10] reported an increased mortality (85.7\%) among Hepatitis B, C patients who are infected by CMV. Another study proved the development of hepatitis by CMV with evident fibrosis of the liver cells. This denotes that CMV can affect the liver cells and can modulate the immune system response [10].

HCMV associated hepatitis can occur as disseminated infection among liver or kidney transplant individuals and other immunocompromised host [5,11], however CMV hepatitis also has been reported in immunocompetent individuals [12]. Mild to moderate elevation of transaminases and diverse histopathological affection of liver cells were documented among those patients [4].

This study aimed to determine the prevalence of HCMV co-infection in patients with chronic HCV and its correlation with HCV viral load in both Clinical Pathology and the Tropical Medicine department, Faculty of Medicine, Zagazig University.

\section{PATIENTS AND METHODS}

This case-control study was conducted in the Clinical Pathology and Tropical Medicine Departments, Zagazig University Hospitals between May 2015 and May 2016. Written informed consents have been signed by all included subjects. It included 120 individuals who were classified into two groups:

(I) Control group: 60 apparently healthy persons (male \& female).

(II) Patient group: 60 chronic HCV patients (Child A according to Child-Pugh classification) that were further subdivided into 4 subgroups according to viral load by quantitative PCR (where lower detection limit assay less than 15 $\mathrm{IU} / \mathrm{mL}$ )

a- Resolved Group (viral load not detected). b- Mild viremia group (viral load: $<200,000$ $\mathrm{IU} / \mathrm{mL}$ ).

c- Moderate viremia group (viral load: 200,000 $-2,000,000 \mathrm{IU} / \mathrm{mL}$ ).

d- Severe viremia group (viral load: more than $2,000,000 \mathrm{IU} / \mathrm{mL}$ ) as measured by the National Genetics Institute assay.

\section{Exclusion criteria:}

Patients who have Diabetes Mellitus, any malignancy and those who treated with corticosteroids or immunosuppressive drugs

\section{II- Methods}

Both patients and control were subjected to

- Full medical history taking.

- Routine laboratory investigations.

- Complete Blood Picture.

- Liver function tests:

- Serum albumin

- Serum bilirubin

- Serum total protein

- ALT, AST and Alkaline phosphatase.

- Random blood glucose level.

- HCV Abs.

- Quantitative PCR for HCV RNA for (patient group).

- HCMV IgG and IgM in serum by Enzyme linked immune assay (ELISA).

- Pelvi-abdominal ultrasonography.

\section{Statistical analysis}

Data were checked, entered and analyzed using SPSS 17 for Windows. Data were expressed as mean \pm SD for quantitative variable, number and percentage for qualitative one. Chi-squared $\left(\mathrm{X}^{2}\right)$ or $\mathrm{t}$ test and paired $\mathrm{t}$ test were used when appropriate. $\mathrm{P}<0.05$ was considered significant $<0.001$ was considered highly significant.

\section{RESULTS}

Demographic data showed that there was nonsignificant difference between cases and control group as regard gender and age $(\mathrm{P}>0.05)$ (Table 1). There was highly statistically significant difference in WBCs, RBCs and Platelets among cases and controls. No significance was found in HB, Lymph., Gran., and MID. among cases and controls (Table 2). There were significant differences in values of ALT, AST and ALP between resolved cases and the other patient subgroups (Table 3). A comparative study of CMV Abs among cases and controls revealing that there was a statistically significant difference 
between cases and controls as regards IgG CMV Abs. There was no statistical significant difference between cases and control as regards IgM CMV Abs (Table 4). There was no significant difference in $\mathrm{IgG}$ and $\mathrm{IgM}$ antibodies (Table 5). However, there was no correlation between PCR and IgG but there was +ve significant correlation between
PCR and IgM (Table 6). There was no correlation between PCR and IgG in all subgroups also no correlation between PCR and IgM in mild and moderate cases but there was positive significant correlation between PCR and $\operatorname{IgM}$ in severe cases (Table 7).

Table (1): Socio-demographic data of control and cases

\begin{tabular}{|c|c|c|c|c|c|}
\hline & \multicolumn{2}{|c|}{$\begin{array}{c}\text { Control } \\
\mathbf{n = 6 0}\end{array}$} & \multicolumn{2}{c|}{$\begin{array}{c}\text { Cases } \\
\mathbf{n = 6 0}\end{array}$} & \multirow{2}{*}{ P value } \\
\cline { 1 - 5 } Age (years) & \multicolumn{6}{|c|}{37.312 .4} & \multicolumn{2}{c|}{37.511 .9} & \multirow{2}{*}{0.89} \\
\hline Mean SD & \multicolumn{2}{|c|}{$21-60$} & \multicolumn{2}{|c|}{$20-62$} & \\
\hline Range & $\mathbf{N}$ & $\mathbf{\%}$ & $\mathbf{N}$ & $\mathbf{\%}$ & \multirow{2}{*}{0.35} \\
\hline Gender & 34 & 56.7 & 40 & 66.7 & \\
\hline Male & 26 & 43.3 & 20 & 33.3 & \\
\hline
\end{tabular}

Table (2): Complete blood count between the studied groups

\begin{tabular}{|c|c|c|c|}
\hline & Controls & Cases & $\mathbf{P}$ value \\
\hline \multicolumn{4}{|l|}{$\mathrm{WBC}\left(\mathrm{x10}^{\wedge} 3 / \mathrm{cm}\right)$} \\
\hline Mean \pm SD & 9.33 .2 & 6.22 .2 & \multirow{2}{*}{$<0.001 * *$} \\
\hline Range & $4.5-18.2$ & $2.1-12$ & \\
\hline \multicolumn{4}{|l|}{ MID (\%) } \\
\hline Mean \pm SD & 8.33 .9 & 7.92 .8 & \multirow{2}{*}{0.51} \\
\hline Range & $4.5-23.1$ & $1.7-13.6$ & \\
\hline \multicolumn{4}{|l|}{ Gran (\%) } \\
\hline Mean \pm SD & 54.59 .9 & 50.714 .6 & \multirow{2}{*}{0.2} \\
\hline Range & $28.1-69.1$ & $17.4-83.9$ & \\
\hline \multicolumn{4}{|l|}{ Lymph (\%) } \\
\hline Mean \pm SD & 37.29 .8 & 41.613 .5 & \multirow{2}{*}{0.11} \\
\hline Range & $23.3-67.4$ & $12.3-71.2$ & \\
\hline \multicolumn{4}{|l|}{ RBCs $\left(\times 10^{\wedge} 6 / \mathrm{cm}\right)$} \\
\hline Mean \pm SD & 4.90 .2 & 4.70 .7 & \multirow{2}{*}{$<0.001 * *$} \\
\hline Range & $4.0-6.8$ & $3.2-5.7$ & \\
\hline \multicolumn{4}{|l|}{ HB (g/dl) } \\
\hline Mean \pm SD & 13.51 .4 & 13.21 .76 & \multirow{2}{*}{0.54} \\
\hline Range & $11.2-16.9$ & $9-15.9$ & \\
\hline \multicolumn{4}{|l|}{ PLT $\left(\times 10^{\wedge} 3 / \mathrm{cm}\right)$} \\
\hline Mean \pm SD & 273.764 & 177.347 & \multirow{2}{*}{$<0.001 * *$} \\
\hline Range & $158-400$ & $101-283$ & \\
\hline
\end{tabular}

**highly significant 
Table (3): Liver function tests in the studied patient's subgroups

\begin{tabular}{|c|c|c|c|c|c|}
\hline & $\begin{array}{c}\text { Resolved } \\
\mathbf{n}=\mathbf{1 0}\end{array}$ & $\begin{array}{c}\text { Mild } \\
\mathbf{n}=\mathbf{1 0}\end{array}$ & $\begin{array}{c}\text { Moderate } \\
\mathbf{n}=\mathbf{2 0}\end{array}$ & $\begin{array}{l}\text { Severe } \\
\mathbf{n}=\mathbf{2 0}\end{array}$ & $\mathbf{P}$ value \\
\hline \multicolumn{6}{|c|}{ Albumin (g/dl) } \\
\hline Mean SD & 4.70 .4 & 4.40 .36 & 4.70 .3 & 4.50 .3 & \multirow{2}{*}{0.08} \\
\hline Range & $3.8-5.2$ & $3.9-5.0$ & $4.1-5.2$ & $4-5.0$ & \\
\hline \multicolumn{6}{|c|}{ Total Bilirubin(mg/dl) } \\
\hline Mean SD & 0.50 .2 & 0.50 .2 & 0.670 .2 & 0.20 .2 & \multirow{2}{*}{0.17} \\
\hline Range & $0.3-0.9$ & $0.5-0.8$ & $0.4-1.3$ & $0.4-1.4$ & \\
\hline \multicolumn{6}{|c|}{ Direct Bilirubin(mg/dl) } \\
\hline Mean SD & 0.160 .09 & 0.140 .05 & 0.140 .07 & 0.150 .1 & \multirow{2}{*}{0.92} \\
\hline Range & $0.1-0.3$ & $0.1-0.2$ & $0.1-0.3$ & $0.1-0.5$ & \\
\hline \multicolumn{6}{|c|}{ Total Protein(g/dl) } \\
\hline Mean SD & 7.21 .1 & 7.40 .7 & 7.70 .6 & 7.10 .8 & \multirow{2}{*}{0.3} \\
\hline Range & $4.6-8.2$ & $6.3-8.3$ & $6.2-8.4$ & $6-8.2$ & \\
\hline \multicolumn{6}{|c|}{ ALT(IU/mI) } \\
\hline Mean SD & $31.98 .6^{*}$ & 42.819 & 44.324 & 57.616 & \multirow{2}{*}{$0.002 * *$} \\
\hline Range & $16-42$ & $26-118$ & $18-119$ & $27-138$ & \\
\hline \multicolumn{6}{|c|}{ AST(IU/ml) } \\
\hline Mean SD & $33.99 *$ & 36.116 & 37.819 & 55.317 & \multirow{2}{*}{$0.018^{*}$} \\
\hline Range & $19-48$ & $21-77$ & $19-80$ & $36-137$ & \\
\hline \multicolumn{6}{|c|}{ ALP(IU/ml) } \\
\hline Mean SD & $46.811^{*}$ & 6612.2 & 69.921 .0 & 76.226 .5 & \multirow{2}{*}{$0.006 * *$} \\
\hline Range & $40-79$ & $50-84$ & $34-110$ & $43-156$ & \\
\hline
\end{tabular}

F test used $=$ ANOVA, $* *$ highly significant

Table (4): Comparative Study of CMV antibodies in cases and controls

\begin{tabular}{|c|c|c|c|c|c|c|}
\hline & \multicolumn{2}{|c|}{ Control } & \multicolumn{2}{|c|}{ Cases } & $\mathbf{T}$ & $\mathbf{P}$ \\
\hline \multicolumn{7}{|l|}{ IgG } \\
\hline Mean SD & \multicolumn{2}{|c|}{1.7581 .5} & \multicolumn{2}{|c|}{3.572 .44} & \multirow{2}{*}{3.72} & \multirow{2}{*}{$<0.001 * *$} \\
\hline Range & \multicolumn{2}{|c|}{$0.07-4.5$} & \multicolumn{2}{|c|}{$0.55-10.09$} & & \\
\hline & & & & & $\chi^{2}$ & \\
\hline Negative & 28 & $46.7 \%$ & 5 & $8.3 \%$ & \multirow{2}{*}{22.1} & \multirow{2}{*}{$<0.001 * *$} \\
\hline Positive & 32 & $53.3 \%$ & 55 & $91.7 \%$ & & \\
\hline \multicolumn{5}{|l|}{ IgM } & \multicolumn{2}{|l|}{ MW } \\
\hline Mean SD & \multicolumn{2}{|c|}{1.32 .09} & \multicolumn{2}{|c|}{1.832 .08} & \multirow{2}{*}{1.69} & \multirow{2}{*}{0.19} \\
\hline Range & \multicolumn{2}{|c|}{$0.02-7.7$} & \multicolumn{2}{|c|}{$0.08-12.4$} & & \\
\hline \multirow[t]{2}{*}{ Median } & \multicolumn{2}{|c|}{0.5} & \multicolumn{2}{|c|}{0.6} & & \\
\hline & & & & & $\chi^{2}$ & \\
\hline Negative & 50 & $83.3 \%$ & 43 & $71.7 \%$ & \multirow{2}{*}{2.34} & \multirow{2}{*}{0.12} \\
\hline Positive & 10 & 16.7 & 17 & 28.3 & & \\
\hline
\end{tabular}

MW = Mann Whitney, $\chi 2=$ Chi square, $* *$ highly significant 
Table (5): Comparative study among patient's subgroups as regard CMV antibodies

\begin{tabular}{|c|c|c|c|c|c|c|}
\hline & $\begin{array}{c}\text { Resolve } \\
\mathbf{n}=\mathbf{1 0}\end{array}$ & $\begin{array}{c}\text { Mild } \\
\mathrm{n}=\mathbf{1 0}\end{array}$ & $\begin{array}{c}\text { Moderate } \\
\mathbf{n}=\mathbf{2 0}\end{array}$ & $\begin{array}{l}\text { Severe } \\
n=20\end{array}$ & $\mathbf{F}$ & $\mathbf{P}$ \\
\hline \multicolumn{7}{|l|}{ IgG } \\
\hline Mean SD & 42.5 & 4.12 .9 & 2.71 .7 & 3.92 .7 & \multirow{2}{*}{1.29} & \multirow{2}{*}{0.28} \\
\hline Range & $1.05-8.35$ & $0.56-8.24$ & $0.71-8.54$ & $0.55-10.9$ & & \\
\hline \multicolumn{5}{|l|}{ IgM } & KW & \\
\hline Mean SD & 0.70 .9 & 1.52 .9 & 2.53 .4 & 1.862 .1 & \multirow{3}{*}{4.6} & \multirow{3}{*}{0.2} \\
\hline Range & $0.08-3.04$ & $0.08-6.75$ & $0.1-12.4$ & $0.23-6.37$ & & \\
\hline Median & 0.36 & 0.54 & 0.56 & 0.7 & & \\
\hline
\end{tabular}

$\mathrm{F}=\mathrm{ANOVA}$

KW: Kruskal Wallis test

Table (6): Correlation between CMV antibodies and HCV RNA-PCR level among cases group

\begin{tabular}{|l|c|c|}
\hline \multirow{2}{*}{} & \multicolumn{2}{|c|}{ RNA-PCR } \\
n= 60 \\
\cline { 2 - 3 } & $\mathbf{r}$ & $\mathbf{P}$ \\
\hline IgG & 0.02 & 0.86 \\
\hline IgM & $\mathbf{0 . 3 0}$ & $0.02^{*}$ \\
\hline
\end{tabular}

*Significant

Table (7): Correlation between CMV antibodies and HCV RNA-PCR level among different cases subgroups

\begin{tabular}{|c|c|c|c|c|c|c|}
\hline & \multicolumn{6}{|c|}{$\begin{array}{c}\text { RNA - PCR } \\
\mathbf{N}=\mathbf{5 0}\end{array}$} \\
\hline & \multicolumn{2}{|c|}{$\begin{array}{c}\text { Mild } \\
\mathrm{n}=\mathbf{1 0}\end{array}$} & \multicolumn{2}{|c|}{$\begin{array}{c}\text { Moderate } \\
\mathbf{n}=\mathbf{2 0}\end{array}$} & \multicolumn{2}{|c|}{$\begin{array}{l}\text { Severe } \\
n=20\end{array}$} \\
\hline & $\mathbf{R}$ & $\mathbf{P}$ & $\mathbf{R}$ & $\mathbf{P}$ & $\mathbf{R}$ & $\mathbf{P}$ \\
\hline IgG & 0.12 & 0.75 & 0.14 & 0.65 & 0.16 & 0.48 \\
\hline IgM & 0.46 & 0.19 & 0.39 & 0.09 & 0.33 & $0.03^{*}$ \\
\hline
\end{tabular}

*Significant

\section{DISCUSSION}

In the present study, it was found that laboratory parameters such as WBCs, RBCs and platelets were significantly different in cases than in control (where $\mathrm{P}<0.001$ ). This finding was in concordance with Chiorean et al. [13], where they found that the hematological parameters showed a high significant difference between controls and chronic $\mathrm{HCV}$ patients.

Blood glucose in the studied groups showed that there was no statistical significance between cases and controls which agreed with Ahmed et al. [14].

We found that ALT, AST and ALP levels were higher in patients than in the control group with significance. It was also found that ALT, AST and ALP levels were significantly higher in other patient subgroups than in the resolved patient subgroup. These findings were in agreement with the finding of Tabll et al. [3] where they reported that both ALT and AST levels were higher in the HCV persistent group than in the spontaneously cleared group and that there was no difference between the spontaneously cleared group and the control group but there were no comments on ALP levels in their study.

Also, there were a high percentage of CMV IgM antibodies among patients group $(28.3 \%)$ than in the control group (16.7\%). This was an agreement with Tabll et al. [3] where they stated that the prevalence of HCMV Abs (IgG \& IgM) were higher in chronic HCV patients than in control subjects. In their study the patient group showed that $87 \%$ of patients were positive for $\operatorname{IgG}$ and $25 \%$ were positive for HCMV IgM, whereas their control group was $53 \%$ and $17.6 \%$ respectively, stating that the prevalence of positive CMV IgG and IgM antibodies was significantly higher in 
chronic $\mathrm{HCV}$ patients than those in spontaneously cleared HCV patients.

In our study, there was no significant difference between the different patients' subgroups as regards IgG and IgM antibodies. On the other hand, Bayram et al. [5] found that the difference in positivity of HCMV IgG abs between the patient and control group was not significant and there were no HCMV IgM abs detected in any serum samples from patient or control groups.

Also, Bayram et al. [5] reported that in HCVpositive group, serum ALT and hepatic activity scores reported to be high in HCMV positive patients compared to HCMV negative patients. Also, other studies stated that both mean ALT and AST levels were higher in HCMV positive patients $[15,16]$.

These findings suggest that HCMV infection in chronic HCV patients has a direct effect on the activity of ALT and AST enzymes by increasing their levels in serum.

Serum total bilirubin levels were also elevated among patients compared to controls and the difference was statistically significant. This finding was congruent with the findings of Chiorean et al. [13].

The present study showed that there was a higher percentage of CMV IgG among patients (91.7\%) compared to controls (53.3\%). No gender preference was noted. This finding was consistent with the findings of Tabll et al. (3).

It was found that HCMV virus exerts an immunomodulatory effect resulting in a state of immunesuppression $[\mathbf{1 7 , 1 8}]$ and cytokines up regulations which accelerate HCV pathogenesis in critically ill patients. The findings of Tabll et al. [3] supported such hypothesis since they reported that low levels of HCMV replication doesn't progress into clinical disease state but can significantly influences HCV outcome. The present study results agree with this hypothesis as our biochemical and laboratory markers were higher in HCMV positive patients.

In our study, we found that there was no correlation between CMV IgG and HCV-RNA PCR levels in the different patient subgroups and also no correlation between IgM and HCV-RNA PCR levels in mild and moderate patient subgroups. On the other hand, there was significant positive correlation between HCV-RNA PCR levels and CMV IgM in severe cases. This indicates that there is an association between
HCV aggressiveness and the possibility of CMV reactivation [3].

Kelly et al. [19] reported that HCMV infection suppresses the cell-mediated immunity and has been reported to be associated with more frequent development of cirrhosis in $\mathrm{HCV}$ infected patients. Julio et al. [20] also concluded that the impact of HCMV infection on HCV infected liver transplant patients is development of hepatitis with and fibrosis of the liver cells. The incidence of cirrhosis was higher in HCV livertransplant recipients with CMV viremia [21].

\section{CONCLUSION}

From the presented data, we can conclude that $\mathrm{CMV}$ infection is common in chronic $\mathrm{HCV}$ patients and there was no correlation between hepatitis $\mathrm{C}$ virus load and CMV IgG but there was positive significant correlation between hepatitis $\mathrm{C}$ virus load and CMV IgM. There was no correlation between hepatitis $\mathrm{C}$ virus load and CMV IgG in all patients subgroups also no correlation between hepatitis $\mathrm{C}$ virus load and CMV IgM in mild and moderate cases but there was positive significant correlation between hepatitis $\mathrm{C}$ virus load and CMV IgM in severe cases. Also, the significant elevation in the serum activity levels of ALT and AST in HCMV/HCV patients than in HCMV patients only, reflects the severity of liver inflammation in HCMV infected chronic HCV patient.

\section{Funding: None}

\section{Conflicts of interest: None}

Informed consents were obtained from all patients.

\section{REFERENCES}

1. Scholz M, Doerr HW, Cinati J. Human cytomegalovirus retinitis: pathogenicity, immune evasion and persistence. Trends Microbiol; 2003, 11(4): 171-178.

2. Gandhi MK, Khanna R. Human cytomegalovirus: Clinical aspects immune regulation, and emerging treatments. Lancet Infect Dis; 2004, 4: 725-738.

3. Tabll A, Sahar S, Hussam G, Mohamed N, Noha GB El-Din, Mostafa K El-Awady. Assessment of human cytomegalovirus co-infection in Egyptian chronic HCV patients. Virology Journal, 2011, 8: 343. 
4. Gredmark S, Jonasson L, Van Gosliga D, Emerudh J, Sderberg-Naucler C. Active cytomegalovirus replication in patients with coronary disease. Scand Cardiovasc J; 2007, 41: 230-234.

5. Bayram A, Ozkur A, Erkilic S. Prevalence of human cytomegalovirus co-infection in patients with chronic viral hepatitis B and C. A comparison of clinical and histological aspects. $J$ Clin Virol, 2009, 45: 212-217.

6. Daar ES, Lynn H, Donfield S, Gomperts E, O'Brien SJ, Hilgartner MW. Hepatitis C virus load is associated with human immunodeficiency virus type 1 disease progression in hemophiliacs. J Infect Dis; 2001, 183: 589-895.

7. Jardi R, Rodriguez F, Buti M, Costa X, Cotrina M, Galimany R. Role of hepatitis B, C and D viruses in dual and triple infection: Influence of viral genotypes and hepatitis B pre core and basal core promoter mutations on viral replicative interference. Hepatology; 2001, 34: 404-410.

8. Park J, Saraf N, Douglas Dieterich D. Antiviral therapy in the HCV co-infected patient with HIV and-or HBV. Current Hepatitis Reports; 2005, 4: 68-74.

9. Bader El-Din NG, Abd El-Meguid M, Tabll AA, Anany MA, Esmat G, Zayed N, et al. Human cytomegalovirus infection inhibits response of chronic hepatitis-C-virus-infected patients to interferon-based therapy. J Gastroenterol Hepatol, 2011, 26 (1): 55-62.

10. Lian Y, Wu W, Shi Y. Preliminary study on relationship between different viral pathogenesis and disease prognosis in patients with severe viral hepatitis; 1999, 13(4): 355-357.

11. Fallahian F, Najafi A. Epidemiology of hepatitis $\mathrm{C}$ in the Middle East. Saudi J Kidney Dis Transpl; 2011, 22: 1-9.

12. Görzer I, Kerschner H, Redlberger-Fritz M, Punchammer-Stckl E. Human cytomegalovirus (HCMV) genotype populations in immunocompetent individuals during primary HCMV infection. J ClinVirol; 2010, 48(2): 100-103.
13. Chiorean E, Miron M, Miron N, Cristea V. Human Cytomegalovirus infection - Prevalence and Biologic Impact within the general population and among the patients with chronic B or C viral Hepatitis. Clinical Medical. Mar, 2010, Vol. 83, no.1, pp 157-162.

14. Ahmed N, Rashid A, Naveed A, Bashir Q. Effect of HCV on fasting glucose, fasting insulin and peripheral insulin resistance in first 5 years of infection. J Pak Med Assoc. 2016, Vol.66, No.2; 140:142.

15. Burak KW, Kremers WK, Batts KP, Wiesner RH, Rosen CB, Razonable RR, et al. Impact of cytomegalovirus infection, year of transplantation, and donor age on outcomes after liver transplantation for hepatitis C. Liver Transpl; 2002, 8, 362-269.

16. Razonable R, Burak K, van Cruijsen H, Brown R, Charlton M, Smith T. The pathogenesis of hepatitis $\mathrm{C}$ virus is influenced by cytomegalovirus. Clin Infect Dis; 2002, 35, 974-81.

17. Lee SO, Razonable RR. Current Concepts on cytomegalovirus infection after liver transplantation. World J Hepatol, 2010, 27; 2(9): 325-336.

18. Varani S, Landini MP. Cytomegalovirus-induced immunopathology and its clinical consequences. Herpesviridae, 2011, 7; 2(1): 6.

19. Kelly W, Carlos V Paya, Walter K Kremers, Russell H Wiesner, Charles B Rosen, Michael R Charlton, et al. The prevalence and impact of cytomegalovirus infection in hepatitis C Patients undergoing liver transplantation. Hepatology; 2001, 943. 408A.

20. Julio C, Medinal, Graciela P, Jose M Interactions between Cytomegalovirus and Other Viruses (HHV6, HHV7, HCV and EBV) in Transplantation. Trends in Transplantation; 2007, 1: $129-136$.

21. Atul H, Deepali K, Janet R, Angela M, Caliendod G, Gary L et al. Interactions between Cytomegalovirus, Human Herpesvirus-6, and the Recurrence of Hepatitis C after Liver Transplantation. American Journal of Transplantation; 2002, 2: 461-466. 